Ramunas Birstonas, Dr. iur.

Vilnius University, Lithuania

Vadim Mantrov, Dr. iur.

University of Latvia, Latvia

Gaabriel Tavits, Dr. iur.

University of Tartu, Estonia

Aleksei Kelli, Dr. iur.

University of Tartu, Estonia

\title{
IMPLEMENTATION OF TRADE SECRETS DIRECTIVE IN BALTIC STATES: A STEP TOWARDS PARTIAL HARMONISATION
}

\begin{abstract}
Summary
Due to low patenting intensity, trade secret protection is the primary tool for the protection of valuable entrepreneurial knowledge base in the Baltic states. The adoption of the Trade Secrets Directive, which aims to harmonize trade secret protection at the European Union level, potentially has a significant impact in the region.

Nevertheless, there are several reasons why the changes brought by the Trade Secrets Directive may not have a desirable harmonization effect. Firstly, it is a minimum harmonization directive which allows more far-reaching protection in the different EU Member States. Secondly, some aspects of the protection of trade secrets are at the discretion of the EU Member States. Two notable examples are the duration of the limitation period and the scope of the lawful acquisition, use and disclosure of a trade secret. Thirdly, the Directive leaves some essential questions outside its scope. One of such issues is the employee's duty of confidentiality, especially after the termination of an employment contract. Besides, the Baltic states differ about the additional level of protection - the so-called "confidential information".

The paper aims to evaluate the implementation models of the Trade Secrets Directive in the national law of the three Baltic states, i.e., Estonia, Latvia, and Lithuania, and to compare them. Likewise, the paper endeavours to highlight the remaining or newly emerged differences in the legal protection of trade secrets. To achieve this aim, the authors analyse the legal regulation of trade secrets in the three Baltic states before and after the implementation of the Trade Secrets Directive.
\end{abstract}

Keywords: trade secrets, Directive 2016/943, implementation, confidential information, remedies, the Baltic states, employee's duty of confidentiality 


\section{Introduction}

Trade secrets have always formed an indispensable part in the overall structure of the protection of valuable information within economic activity. Nowadays, trade secrets are becoming even more critical ${ }^{1}$. The recent acknowledgement of the importance of trade secret protection is reflected in the legislative trend across the globe. Particular examples of this process are the Defend Trade Secrets Act in the US (in 2016) ${ }^{2}$, the EU Directive on the protection of undisclosed know-how and business information (trade secrets) against their unlawful acquisition, use and disclosure (hereinafter - the Directive) ${ }^{3}$ (also in 2016), and amendments to the Chinese Anti-Unfair Competition Law, dealing with trade secrets protection (in 2018 and 2019) $)^{4}$.

Trade secret protection is especially relevant for the Baltic states (Lithuania, Latvia and Estonia) for several reasons. To understand the context, it should be explained that patent intensity is rather low in the Baltics. For instance, patent applications by residents in 2017 were 105 for both Lithuania and Latvia and 91 for Estonia $^{5}$. The other reason is the perceived affordability of trade secrets protection. This understanding is caused by lower cost and more lenient requirements of this form of protection. The legal protection of trade secret is automatic since its creation and, therefore, does not require filing and registration or other formal actions. This form of protection is especially relevant for small and medium enterprises when comparing with the classical industrial property rights. Trade secret protection is also used in combination with other intellectual property instruments ${ }^{6}$.

The legal regulation of the trade secrets in the Baltic states (as well as in the other EU Member States) was changed recently due to the implementation of the Directive, which aims to harmonize trade secret protection at the European Union level. Nevertheless, there are at least three reasons why the changes brought by the Directive may not have a desirable harmonization effect even in the comparatively similar jurisdictions of Lithuania, Latvia and Estonia. Firstly, it

1 For reasons explaining the growing importance of trade secrets, see Almeling D. S. Seven Reasons Why Trade Secrets are Increasingly Important. Berkeley Technology Law Journal, Vol. 27, 2012, p. 1091; Lewine D. S., Sichelman T. Why Do Startups Use Trade Secrets? Notre Dame Law Review, Vol. 92, 2018, p. 751; Sibble J. International Trend Toward Strengthening Trade Secret Law. Intellectual Property \& Technology Law Journal, Vol. 26, No. 4, 2014, p. 18.

2 Defend Trade Secrets Act of 2016. Available at: https://www.congress.gov/114/plaws/publ153/ PLAW-114publ153.pdf [last viewed November 1, 2019].

3 Directive (EU) 2016/943 of the European Parliament and of the Council of 8 June 2016 on the protection of undisclosed know-how and business information (trade secrets) against their unlawful acquisition, use and disclosure, 2016 OJ (L 157).

4 Cyrill M. China Reinforces IP Laws to Protect Trademarks, Trade Secrets. Available at: https://www.china-briefing.com/news/china-ip-protections-trademarks-trade-secrets/ [last viewed October 10, 2019].

5 Source: WIPO Statistics database. Available at: https://www.wipo.int/ipstats/en/statistics/ country_profile/ [last viewed October 10, 2019].

6 See Kelli A., Mets T., Pisuke H., Vasamäe E., Värv A. Trade Secrets in the Intellectual Property Strategies of Entrepreneurs: The Estonian Experience. Review of Central and East European Law, No. 35, 2010, p. 315. 
is a minimum harmonization directive, which allows more far-reaching protection in the different EU Member States. Secondly, some aspects of the protection of trade secrets are at the discretion of the EU Member States. To mention just a few examples: the EU Member States can decide upon the duration of the limitation period (Art. 8), the scope of the lawful acquisition, use or disclosure of a trade secret (Art. 3(2)), the restrictions of employees' civil liability (Art. 14(1)). Thirdly, the Directive leaves some essential questions outside its scope. The most prominent examples are unfair competition law, which traditionally deals with the protection of trade secrets. Besides, the Baltic states differ about the broader level of protection exceeding trade secret protection, which is usually covered by the term "confidential information".

The paper aims to evaluate the implementation models of the Directive in national law of three Baltic states and to compare them. By doing this, the paper endeavours to highlight the remaining or newly emerged differences in the legal protection of trade secrets in the Baltic states. To achieve this aim, the authors analyse the legal regulation of trade secrets in the three Baltic states before and after the implementation of the Trade Secrets Directive, also taking into account the developments of court practice in each Baltic state?

\section{Protection of trade secrets in the Baltic states before the Directive}

One of the main reasons for the enactment of the Directive was different approaches to trade secret protection and different effectiveness of the latter in the EU Member States ${ }^{8}$. It is true that all EU Member States, being bound by Art. 39 of the Agreement on Trade-Related Aspects of Intellectual Property Rights ${ }^{9}$ (hereinafter - the TRIPS Agreement), had the protection of trade secrets in one form or another. However, the important differences, creating obstacles to the common

\footnotetext{
The Directive itself is not analysed in this article. For a general overview of the Directive and its particular provisions, see Aplin T. A Critical Evaluation of the Proposed EU Trade Secrets Directive. King's College London Dickson Poon School of Law Legal Studies Research Paper Series. London: The Dickson Poon School of Law, paper No. 2014-25. 2014; Falce V. Trade secrets - looking for (full) harmonization in the Innovation Union. International Review of Intellectual Property and Competition Law, No. 48(8), 2015, p. 940; Knaak R., Kur A., Hilty R. Comments of the Max Planck Institute for Innovation and Competition on the Proposal of the European Commission for a Directive on the protection of undisclosed know-how and business information (trade secrets) against their unlawful acquisition, use and disclosure of 28 November 2013, $\operatorname{COM(2013)~} 813$ final. Max Planck Institute for Innovation and Competition Research Paper No. 1411; Lapousterle J. et al, What Protection for Trade Secrets in the European Union? CEIPI'S Observations on the Proposal for a Directive on the protection of undisclosed know-how and business information. Centre for International Intellectual Property Studies Research Paper No. 2015-02, 2015; Torremans P. The Road towards the Harmonisation of Trade Secrets Law in the European Union. Revista La Propiedad Inmaterial, No. 20, 2015, p. 27.

8 Recital 6 of the Directive.

9 Agreement on Trade-Related Aspects of Intellectual Property Rights. Signed in Marrakesh on 15.04.1994.
} 
market, persisted. This problem was highlighted by the studies commissioned by the Commission ${ }^{10}$. The most pressing discrepancies concerned the legal protection model, definition of trade secrets, available remedies and protection of the confidentiality of trade secrets during litigation.

The same problems could have been noticed in the Baltic states. Despite all their similarities in terms of their modern (legal) history, market size, development and close ties among themselves, Lithuania, Latvia and Estonia had quite different regulation of trade secrets before the implementation of the Directive. To begin with Lithuania, trade secrets protection was based on two separate legal bases. First of all, Art. 1.116(1) of the Civil Code provided with the definition of trade secrets ${ }^{11}$ and this factor placed Lithuania among the minority of the EU Member States, which had legal definition before the implementation of Directive. Lithuanian courts interpreted the definition from the perspective of the TRIPS Agreement and distinguished three requirements for the protection: secrecy, commercial value and reasonable efforts to keep the information secret. Also, Art. 1.116 of the Civil Code contained a specific restriction on the information, which could be considered a trade secret and, most importantly, it established a liability for persons who unlawfully disclose trade secrets. This provision was considered as an independent (sui generis) basis of trade secrets protection ${ }^{12}$. The second legal ground for trade secrets protection is found in the Lithuanian Law on Competition. In this law, the unlawful appropriation of trade secrets was considered as a particular case of unfair competition. Therefore, even before the implementation of the Directive, the Lithuanian law recognized the dual grounds of trade secret protection: one based on the protection against the unfair competition and, second - based on the sui generis protection regime ${ }^{13}$.

10 Hogan Lovells International, Study on Trade Secrets and Parasitic Copying (Look-alikes), MARKT/2010/20/D: Report on Trade Secrets for the European Commission, 2012, p. 43; Baker \& Mackenzie. Study on Trade Secrets and Confidential Business Information in the Internal Market, MARKT/2011/128/D, 2013.

11 Art. 1.116(1): "Information shall be considered to be a trade secret if a real or potential commercial value thereof manifests itself in what is not known to the third person and cannot be freely accessible because of the reasonable efforts of the owner of such information, or of any other person entrusted with that information by the owner, to preserve its confidentiality."

12 This view was established in the Lithuanian case law. See Judgment of Lithuanian Supreme Court of 5 February 2016 in case No. 3K-7-6-706/2016. Available at: http://liteko.teismai.lt/ viesasprendimupaieska/tekstas.aspx?id=54e950b3-eaee-4ee0-865f-a7fa0e41cf39 [last viewed November 2, 2019].

13 Birstonas R. New Trade Secrets Directive and Its Implementation into Lithuanian Law. Available at: https://papers.ssrn.com/sol3/papers.cfm?abstract_id=3387094 [last viewed October 31, 2019], pp. $7-8$. 
Regarding Latvia, no definition of trade secrets was enacted before the implantation of the Directive ${ }^{14}$. Likewise, legal protection of trade secret in national law was scattered among different legal acts containing legal norms on protection of trade secret falling either within public or private law depending on a legal relationship which is regulated ${ }^{15}$.

Nevertheless, according to Art. 19 of the Commercial Act, the status of a commercial secret may have been assigned by a merchant for matters of economic, technical or scientific nature to information complying with the following criteria:

1) it is contained in the undertaking of the merchant or is directly related to it;

2) it is not generally accessible to third parties;

3 ) it is of an actual or potential financial or non-financial value;

4) its coming at the disposal of another person may cause losses to the merchant;

5) the merchant has taken reasonable measures to preserve secrecy.

This legal provision can be considered as the workable definition of trade secrets. Nevertheless, the differences in comparison to the Lithuanian regulation should be noticed. First of all, while Lithuanian definition was based on the three requirements, the Latvian counterpart used five requirements, adding, that information under consideration should be contained in the undertaking of the merchant or is directly related to it and that it is coming at the disposal of another person may cause losses to the merchant. These additional requirements made Latvian understanding of trade secrets narrower comparing to Lithuanian one. The second difference, which is directly linked to the additional requirements, is that Latvian definition was binding to the merchants only. This again was different from Lithuania, where the definition provided in the Civil Code had a general application and covered not only merchants, but all persons.

Yet another understanding of trade secret was provided in Art. 7(1) of the Freedom of Information Law ${ }^{16}$, but this act was supposed to belong to the public law sphere. In any case, the definition introduced by the Trade Secrets Directive complicated things even further in Latvia concerning interrelation between

14 Mantrov V. Latvia: Trade secrets: Overlap with restraint of trade, aspects of enforcement (Q247). Available at: https://aippi.org/wp-content/uploads/committees/247/GR247latvia.pdf [last viewed October 31, 2019]. But see the opposite view: Rasnacs L. Potential Improvements in the Laws of the Republic of Latvia Concerning the Protection of the Trade Secrets. In: Legal Science: Functions, Significance and Future in Legal Systems: Collected conference papers of the $7^{\text {th }}$ International Scientific Conference of the Faculty of Law of the University of Latvia. Riga: University of Latvia Press, 2019, p. 194; Strupišs G. Komerclikuma komentāri: A daḷa: Komercdarbības vispārīgie noteikumi (1.-73.pants) [Commercial Law Commentary: Part A: General Conditions of Business (Art. 1-73)]. Rīga: A.Strupiša juridiskais birojs, 2003, p. 106.

15 See generally Mantrov V. Latvia: Trade secrets: Overlap with restraint of trade, aspects of enforcement (Q247). Available at: https://aippi.org/wp-content/uploads/committees/247/ GR247latvia.pdf. [last viewed October 31, 2019].

16 Section 7 of the Freedom of Information Law: "(1) Information, which is created by a merchant or belongs to a merchant and the disclosing of which may have a significant adverse impact on the competitiveness of the merchant, shall be regarded to be a commercial secret." 
this definition and the understanding of trade secret included in Art. 19(1) of the Commercial Act and Art. 7(1) of the Freedom of Information Law.

In Estonia, the situation was even more complicated. The Estonian Competition Act provided the following definition of trade secret: "Information concerning the business activities of an undertaking the communication of which to other persons is likely to harm the interests of such undertaking, above all, technical and financial information relating to know-how, information concerning the methodology of validation of expenditure, production secrets and processes, sources of supply, volumes of purchase and sales, market shares, clients and distributors, marketing plans, expenditure and price structures and sales strategy are deemed to be business secrets" $(\$ 63(1))^{17}$. Instead of formal requirements, a representative list of possible trade secrets was presented. This provision was given in the context of actions of the competition authority. However, it was interpreted as a general norm for the explanation of trade secrets. In the context of disputes relating to trade secrets, the Estonian Supreme Court has relied on the criteria set forth in the Art. 39 of the TRIPS Agreement ${ }^{18}$.

Summing up, the situation in the Baltic states differed significantly: Lithuania had a quite clear definition, while Latvia had a narrower understanding of trade secrets within private law, confined solely to merchants. In Estonia, no general definition was given. The provided definition was intended for the Estonian Competition Authority; however, it was referred to in disputes together with the TRIPS Agreement Art. 39. These conceptual differences in defining trade secrets caused considerable practical uncertainty. Latvian stakeholders, in particular, expressed the position that lack of clarity was detrimental to enforcement of trade secrets protection ${ }^{19}$. Quite a different situation prevailed in Lithuania, where the trade secrets litigation was active and efficient.

17 The provision is repealed with the enactment of the Directive.

18 For instance, Judgment of the Supreme Court of Estonia of 21 March 2007 in case No. 3-2-1-22-07. Available at: https://www.riigikohus.ee/et/lahendid?asjaNr=3-2-1-22-07 [last viewed November 2, 2019].

19 European Union Intellectual Property Office. The Baseline of Trade Secrets Litigation in the EU Member States. Available at: https://euipo.europa.eu/tunnel-web/secure/webdav/guest/ document_library/observatory/documents/reports/2018_Baseline_of_Trade_Secrets Litigations_in_EU_Member_States/2018_Baseline_of_Trade_Secrets_Litigations_in_EU_ Member_States_EN.pdf [last viewed November 1, 2019] ], p. 176 


\section{Situation in the Baltics after the implementation of the Directive}

\subsection{Legislative grounds and scope of protection}

All three Baltic countries implemented the Directive by introducing new legal acts. In Lithuania, the new Law on Legal Protection of Trade Secrets ${ }^{20}$ (hereinafter Lithuanian LTS) was enacted. Alongside, the former definition in the Civil Code was amended to fully meet the definition as provided in the Directive, and to the Code of Civil Procedure the new provisions, transposing the duty to ensure confidentiality during the litigation were added. Provisions of Lithuanian Law on Competition were not affected; therefore, the pre-existing dual basis of trade secrets protection (sui generis and protection against unfair competition) remains.

In Latvia, the new Trade Secret Protection Act ${ }^{21}$ (hereinafter - Latvian TSPA) was enacted, which closely follows the text of the Directive, and the Code of Civil Procedure was amended by adding Chapter $30^{8}$. The old statutory provisions of the Commercial Act were retained. Similarly to Lithuania, this creates dual grounds for protection of trade secrets in Latvia at least with regard to merchants, as the Commercial Act deals solely with regulation of merchants ${ }^{22}$.

In Estonia, the implementation took a slightly different course with a new Restriction of Unfair Competition and Protection of Business Secrets $\mathrm{Act}^{23}$ (hereinafter - Estonian PBSA). The difference is that the new law is broader and encompasses (other) unfair competition. Besides, in this law, trade secrets are expressly named as a particular case of protection against unfair competition. Also, the new provisions were added to the existing regulation on trade secret protection in the Code of Civil Procedure.

To conclude, both Lithuania and Latvia have enacted a sui generis regulation, not identical and going beyond unfair competition law ${ }^{24}$. Meanwhile, in Estonia, trade secrets are regarded as a particular case of unfair competition.

20 Law on Legal Protection of Trade Secrets of Lithuania. Available at: https://e-seimas.lrs.lt/ portal/legalAct/lt/TAD/86178ae24dfb11e88525a4bc7611b788?jfwid=-11gea3wdkd [last viewed October 30, 2019].

21 Trade Secret Protection Act of Latvia. Available at: https://likumi.lv/ta/id/305532komercnoslepuma-aizsardzibas-likums [last viewed October 30, 2019].

22 For an overview of the regulation of commercial law in Latvia including regulation on commercial transactions, see Kārkliņš J., Mantrov V. Commercial law. In: Kerikmäe T., Joamets K., Pleps J., Rodina A., Berkmanas T., Gruodyte E. The Law of the Baltic States. Cham: Springer, 2017, p. 304.

23 Restriction of Unfair Competition and Protection of Business Secrets Act of Estonia. English translation available at: https://www.riigiteataja.ee/en/eli/520122018013/consolide [last viewed November 2, 2019].

${ }^{24}$ In Lithuania, the question between the Lithuanian LTS and Law on Competition was raised during the debates in the Parliament. The answer was given that while Law on Competition requires additional conditions to establish a goal to compete, seeking self-benefit or inflicting damage, sui generis legislation is broader. 


\subsection{Definition of trade secrets and its exceptions}

All three newly enacted laws in the Baltic states contain definitions of trade secret (in Art. 1.116 of the Lithuanian Civil Code, Art. 2 of the Latvian TSPA and Art. 5(2) of the Estonian PBSA respectively), which is almost identical to the one required by the Directive (Art. 2(1)). Only minor differences can be noticed. Firstly, the Latvian definition omits the phrase "as a body or in the precise configuration and assembly of its components". Secondly, both Lithuanian and Latvian definitions clarify that the commercial value of the trade secret (i.e., the second requirement) can be real or potential. Lastly, the Latvian definition, in contrast to the Directive, specifies that trade secret is undisclosed economic information, technological knowledge and information of a scientific or other nature. Arguably, none of these differences are of real practical value, if national courts will interpret and apply respective laws in accordance with the Directive.

A more significant difference is that both Lithuanian and Latvian laws provide the categories of information that are not regarded as trade secrets, while Estonian law has no such list of exemptions. Important to notice, that the Directive itself in the normative part does not set down such a list. Nevertheless, in the recital 14 it specifies that the definition of trade secret excludes trivial information and the experience and skills gained by employees in the normal course of their employment, and also excludes information which is generally known among, or is readily accessible to, persons within the circles that normally deal with the kind of information in question. However, both Lithuanian and Latvian laws are not identical to this provision. Thus, in Lithuania, the following types of information are excluded from the scope of the definition of trade secret (Art. 1.116(2) of the Civil Code):

1) information which is confidential but does not meet the requirements of the trade secret;

2) information that the holder identifies as confidential, but which is obvious (widely known), made public or readily available within the circles that normally deal with the kind of information in question;

3) information which, in the normal course of work, becomes the experience, skills, ability or knowledge of workers in good faith;

4) information on the prices and operating costs of services and goods provided by entities which activities are connected to the public interest;

5) other information which is provided for in the law.

Latvia, on the other hand, excludes:

1) information related to the performance of functions or tasks of the State administration, as well as, in the cases specified in regulatory enactments, handling of state or local government financial resources or property;

2) information and data which, in accordance with regulatory enactments, shall be included in the accounts of natural or legal persons engaged in economic activity. 
As it was already noted Estonian law provides no exclusions. Thus, while all three Baltic states have an almost identical definition of trade secrets, they have different approach to what is not considered as trade secrets. This situation is a potential source of future divergence.

\subsection{Lawful acquisition, use and disclosure of trade secrets}

The Directive describes a lawful acquisition, use and disclosure of trade secrets in Art. 3. Lithuanian LTS just copies these provisions. Meanwhile, Latvian TSPA in its Art. 4 omits lawful use and disclosure, and deals only with lawful acquisition. This makes Latvian TSPA somewhat narrower, comparing to the Lithuanian law and the Directive itself.

The most divergent in this respect is Estonian PBSA, which does not transpose Art. 3 of the Directive, and does not address the issue of lawful acquisition, use and disclosure altogether. According to the Explanatory Memorandum to the draft Restriction of Unfair Competition and Protection of Business Secrets Act of Estonia, the law regulates the unlawful acquisition, use and disclosure of trade secrets and it does not provide instances when the described activities are lawful. The approach is based on the logic of Estonian private law formulated according to the following principle: "Everything which is not forbidden is allowed". To sum up, if the acquisition, use or disclosure of trade secrets is not unlawful, then it is lawful and allowed. The Estonian law should also be interpreted in the light of the Directive ${ }^{25}$.

It can be seen that all three jurisdictions implemented Art. 3 of the Directive in a different way.

\subsection{Unlawful acquisition, use and disclosure of trade secrets}

Implementing Art. 4 of the Directive ("Unlawful acquisition, use and disclosure of trade secrets"), Lithuanian and Estonian laws repeat the provisions of the Directive. However, Art. 5 of Latvian TSPA, while closely following the Directive, does not make a distinction between the unlawful acquisition on the one hand, and unlawful use and disclosure on the other, although such distinction is found in the Directive. Article 5(1) of the Latvian TSPA defines all these infringing activities jointly without setting them apart, as it is provided in Article 4(2)-(4) of the Directive. This leads to logical problems, for instance, whether the breach of the duty for non-disclosure of the trade secret also means its acquisition. Thus, the drafting of the Latvian TSPA might create additional problems in practice with the application of this Act. Likewise, these three infringing acts are considered as established jointly if any of the infringing situations referred to in above Directive's provision are established. This leaves doubts whether the provision of the Directive was implemented into Latvian law correctly and what practical consequences can be expected.

25 Explanatory memorandum to the draft Restriction of Unfair Competition and Protection of Business Secrets Act of Estonia. Available at: https://www.riigikogu.ee/tegevus/eelnoud/eelnou/9b6f21b8db1c-436d-a045-326913d80d22 [last viewed November 2, 2019]. 


\subsection{Remedies}

One of the most important aims of the Directive was the harmonisation of civil remedies. Even though all three countries precisely transposed all the remedies listed in the Directive, several significant deviations can be indicated.

Firstly, Art. 8(2) of Latvian TSPA states that the following remedies: destruction or transfer of material containing trade secrets, the destruction, recall or withdrawal from the market of the infringing goods, elimination of the characteristics of the infringement for the infringing goods and publication of the judgment, can be applied only simultaneously with the injunctions and recovery of damages. This statutory condition is not in line with the text of the Directive and aggravates the enforcement of trade secret protection. Furthermore, it causes a discrepancy between the Latvian law on the one hand and Lithuanian and Estonian law (which does not contain a similar requirement) on the other. The solution to this problem could be the interpretation of Art. 8(2) of Latvian TSPA in conjuncture with the Directive that could lead to the application of this provision consistently with this Directive.

Secondly, considering damages, a quite significant departure from the Directive should be noted, because all three Baltic states alongside the pecuniary damage also introduced non-pecuniary damage (Art. 7 of Lithuanian LTS, Art. 8 of Latvian TSPA and Art. 8 of Estonian PBSA). It is remarkable, because traditionally nonpecuniary damage is associated with a violation of the personal rights of the physical person. While the introduction of non-pecuniary damage goes beyond the Directive, there is no difference among the Baltic states. This choice, arguably, does not violate the requirements of the Directive either, because, as was indicated, the Member States can provide for more far-reaching protection.

Thirdly, the Directive (Art. 8(1)) allows the Member States to limit the liability for damages of employees towards their employers for the unlawful acquisition, use or disclosure of a trade secret of the employer where they act without intent. Lithuanian law has not used this opportunity, and while Lithuanian Labour Code is not totally clear in this respect, it provides for an unlimited liability for violations of the duty of confidentiality.

As regards Latvia, the Latvian TSPA did not use this option, therefore, leaving employees without such an additional protection. As a consequence, employees would be obliged to compensate damages incurred on the basis of either general (fault) liability model or strict liability model envisaged by Latvian civil law and repeated by the Latvian Labour Act. Specifically, according to Art. 86(1) of that Act, if an employee does not perform work without a justifiable reason or performs it improperly, or due to other illegal or culpable action has caused losses to the employer, the employee has an obligation to compensate for the losses caused to the employer.

Estonian Employment Contracts Act (hereinafter - ECA) did not have any amendments in this regard. According to the ECA the liability of an employee is connected to consideration whether the damages were caused intentionally or 
due to negligence ${ }^{26}$. In cases when the disclosure of a trade secret was intentional, the damages caused must be fully compensated by the employee. If the disclosure has happened due to negligence, the amount of the compensation can be different from full to partial reimbursement of damages. It mostly depends on the employer's or court's decision.

Fourthly, one of the provisions of the Directive, which enabled the discretion of national legislators, was Art. 6 dealing with limitation periods. It was up to the Member States to choose the particular duration of the limitation period, which shall not exceed six years. Notwithstanding, all three Baltic countries introduced the same 3-year limitation period.

\subsection{Related issues}

\subsubsection{Post-employment confidentiality duty}

One of the crucial questions which are regulated in the Directive only in a fragmentary and abstract way is the existence of the duty not to disclose trade secrets. This question is the more pressing, taking into account that the majority of unlawful appropriation cases concerns employees (including former employees). The Directive (Art. 4(3)(b)) in this regard gives only a general statement that the disclosure of a trade secret shall be considered unlawful whenever carried out, without the consent of the trade secret holder, by a person being in breach of a confidentiality agreement or any other duty not to disclose the trade secret. The substantiation of the duty not to disclose the trade secret is therefore left for the Member States. The answer is more evident concerning the employee's duty to protect trade secrets of the employer during employment: in all Baltic states, there exists a clear understanding that during the employment, the employee is bound by statutory duty not to disclose the employer's trade secrets. However, as to how is this duty should be applied after the termination of an employment contract, there is no uniform answer.

In Lithuania, this question is directly addressed in Art. 15 of the Law on Competition. This article prescribes that post-employment confidentiality duty lasts one year after the termination of the employment relationship, unless otherwise provided by law or contract. Non-disclosure clauses or contracts are widespread in practice.

In Latvia, both the Trade Secret Protection Act and the Labour Act provides a duty for non-disclosure (Article 5 of Latvian TSPA; Article 83(1), the first sentence of the Labour Act). Though neither of these legal acts explicitly states the period for this duty, it may be assumed that it is permanent. As the Labour Act provides duty for non-disclosure by envisaging that an employee has the obligation not to disclose any information brought to his or her knowledge, which is a commercial secret of the employer (Article 83(1), the first sentence of the Labour Act), this provision

$26 \$ 74(1)$ and (2) Employment Contracts Act of Estonia. Available at: https://www.riigiteataja.ee/ en/eli/509052019005/consolide [last viewed November 2, 2019]. 
could be interpreted broadly by providing such duty in respect of the active or former labour relationships. This conclusion is confirmed in Latvian court practice as the Supreme Court refused the allegation that the former employee could not be under that duty after termination of labour contract relationships. For the sake of truth, it should be noted that this conclusion was made on the basis of Article 19 of the Commercial Act (it was in the time when the Trade Secret Protection Act was not even drafted) but not on the basis of Article 83 of the Labour Act ${ }^{27}$. Employers also usually include a confidentiality clause in an employment contract or - not so frequently - conclude a separate confidentiality contract.

In Estonia, the Employment Contracts Act makes a reference to the Law of Obligations Act $(\$ 625)$, which states that the employee's confidentiality duty shall continue after the expiry of the authorization agreement to the extent needed to protect the legitimate interests of the employer. As in Latvia and Lithuania, in Estonian practice it is usually contractually determined for how long the trade secret has to be kept secret. If not, then the legitimate interest of the employer needs to be followed.

Consequently, all three countries have different regulations and the duration of the post-employment confidentiality duty.

\subsubsection{Confidential information}

Notable peculiarities of Latvian and Lithuanian law are related to the recognition of a specific category of confidential information, which goes beyond the concept of trade secret, while in Estonia such an additional layer of protection is not recognised.

In particular, in Lithuania, this specific category was introduced by court practice. In its decision of 2016, Lithuanian Supreme Court stated:

The category of confidential information goes beyond the legal category of trade secrets, so trade secrets are one type of confidential information. Information that does not meet the requirements of commercial secrecy may fall under the definition of confidential information and be protected on this basis. The information that makes up the content of confidential information is not always a trade secret.

The obligation to protect confidential information generally exists where it is provided for in the contract, whereas the obligation to protect commercial secrets derives in particular from the law. ${ }^{28}$

Although the category of confidential information was never explained in greater detail by the Lithuanian Supreme Court, during the implementation of the Directive this category was expressly added to the Lithuanian Civil Code and now has a statutory basis.

27 Judgment of the Supreme Court of the Republic of Latvia of 27 February 2015 in case No. SKC0008/2015 (C29206608). Available at: https://manas.tiesas.lv/eTiesasMvc/nolemumi/pdf/ 204582.pdf [last viewed November 2, 2019].

28 Judgment of Lithuanian Supreme Court of 5 February 2016 in case No. 3K-7-6-706/2016. Available at: http://liteko.teismai.lt/viesasprendimupaieska/tekstas.aspx?id=54e950b3-eaee-4ee0$865 f-a 7 f a 0 e 41$ cf39 [last viewed November 2, 2019]. 
As in Lithuania, Latvian court practice recognised an additional layer of protection in labour relationships, transcending the protection of trade secrets. The basis for such recognition was Section 83 of Latvian Labour Act ("Nondisclosure Obligation"), which imposes an obligation to an employee not to disclose any information brought to his or her knowledge, which is a commercial secret of the employer. The Supreme Court of the Republic of Latvia, interpreting this provision stated that:

Although the information in question was not classified as a trade secret, there was sufficient reason to treat such information as confidential because it was intended for internal use by the employer and related to its commercial activities.

The employee's job description included, among other things, the employee's responsibility for maintaining confidentiality and loyalty, so the court found that unlawful conduct was not limited to the disclosure of trade secrets, but could also include disclosure of other confidential information prohibited by job description, rules of procedure and other documents. ${ }^{29}$

The availability of the protection of confidential information differs from Estonian law, which does not recognize such a category. If the category of confidential information will be further recognized and developed in Lithuania and Latvia, but not in Estonia, it could result in significant practical enforcement differences among the Baltic states.

\section{Conclusions}

Summing up the analysis above, the following conclusions can be made:

1. After the implementation of the Directive, the statutory regulation of the protection of trade secrets in the Baltic states is to a large extent harmonised. Arguably, this would also lead to a more uniform enforcement.

2. Despite the aforementioned harmonisation, quite many statutory differences in the new legislation among the Baltic states can still be detected. The majority of these differences are not directly connected with the "minimum harmonization" approach or dispositive provisions of the Directive. While these could be considered as the most probable reasons for the deviation, the analysis shows that all three jurisdictions selected very similar or identical solutions (in particular, regarding the duration of the limitation period, nonpecuniary damage). In contrast, the main differences stem from the different implementation of the imperative norms of the Directive.

3. There are important differences in the related matters, not covered in the Directive, in particular, the protection of confidential information, which goes beyond the protection of trade secrets, and post-employment duty to protect trade secrets.

29 Judgment of the Supreme Court of the Republic of Latvia of 19 November 2003 in case No. SKC-546. 
4. Therefore, despite the partial harmonization, quite many significant differences concerning the protection of trade secrets among the Baltic states remain. The future of the case law can either alleviate these differences or, on the contrary, to expand them even further.

\section{BIBLIOGRAPHY}

\section{Literature}

1. Almeling D. S. Seven Reasons Why Trade Secrets are Increasingly Important. Berkeley Technology Law Journal, Vol. 27, 2012, p. 1091.

2. Aplin T. A Critical Evaluation of the Proposed EU Trade Secrets Directive. In: King's College London Dickson Poon School of Law Legal Studies Research Paper Series. London: The Dickson Poon School of Law, paper No. 2014-25, 2014.

3. Baker \& Mackenzie. Study on Trade Secrets and Confidential Business Information in the Internal Market, MARKT/2011/128/D, 2013.

4. Birstonas R. New Trade Secrets Directive and Its Implementation into Lithuanian Law. Available at: https://papers.ssrn.com/sol3/papers.cfm?abstract_id=3387094 [last viewed October 31, 2019].

5. Cyrill M. China Reinforces IP Laws to Protect Trademarks, Trade Secrets. Available at: https://www.china-briefing.com/news/china-ip-protections-trademarks-trade-secrets/ [last viewed October 10, 2019].

6. Explanatory memorandum to the draft Restriction of Unfair Competition and Protection of Business Secrets Act of Estonia. Available at: https://www.riigikogu.ee/tegevus/eelnoud/ eelnou/9b6f21b8-db1c-436d-a045-326913d80d22 [last viewed November 2, 2019].

7. European Union Intellectual Property Office. The Baseline of Trade Secrets Litigation in the EU Member States. Available at: https://euipo.europa.eu/tunnel-web/secure/ webdav/guest/document_library/observatory/documents/reports/2018_Baseline_of_ Trade_Secrets_Litigations_in_EU_Member_States/2018_Baseline_of_Trade_Secrets_ Litigations_in_EU_Member_States_EN.pdf [-̄ast viewed November 1, 2019].

8. Falce V. Trade secrets - looking for (full) harmonisation in the Innovation Union. International Review of Intellectual Property and Competition Law, No. 48(8), 2015, p. 940.

9. Hogan Lovells International, Study on Trade Secrets and Parasitic Copying (Look-alikes), MARKT/2010/20/D: Report on Trade Secrets for the European Commission, 2012.

10. Kārkliņš J., Mantrov V. Commercial law. In: Kerikmäe T., Joamets K., Pleps J., Rodina A., Berkmanas T., Gruodyte E. The Law of the Baltic States. Cham: Springer, 2017, p. 304.

11. Kelli A., Mets T., Pisuke H., Vasamäe E., Värv A. Trade Secrets in the Intellectual Property Strategies of Entrepreneurs: The Estonian Experience. Review of Central and East European Law, No. 35, 2010, p. 315.

12. Knaak R., Kur A., Hilty R. Comments of the Max Planck Institute for Innovation and Competition on the Proposal of the European Commission for a Directive on the protection of undisclosed know-how and business information (trade secrets) against their unlawful acquisition, use and disclosure of 28 November 2013, COM(2013) 813 final. Max Planck Institute for Innovation and Competition Research Paper No. 14-11, 2014.

13. Lapousterle J. et al. What Protection for Trade Secrets in the European Union? CEIPI'S Observations on the Proposal for a Directive on the protection of undisclosed know-how and business information. Centre for International Intellectual Property Studies Research Paper No. 2015-02, 2015. 
14. Lewine D. S., Sichelman T. Why Do Startups Use Trade Secrets? Notre Dame Law Review, Vol. 92, 2018, p. 751.

15. Mantrov V. Latvia: Trade secrets: Overlap with restraint of trade, aspects of enforcement (Q247). Available at: https://aippi.org/wp-content/uploads/committees/247/GR247latvia. pdf [last viewed October 31, 2019].

16. Rasnačs L. Potential Improvements in the Law of the Republic of Latvia Concerning the Protection of the Trade Secrets. In: Legal Science: Functions, Significance and Future in Legal Systems: Collected conference papers of the $7^{\text {th }}$ International Scientific Conference of the Faculty of Law of the University of Latvia. Riga: University of Latvia Press, 2019, p. 193.

17. Sibble J. International Trend Toward Strengthening Trade Secret Law. Intellectual Property \& Technology Law Journal, Vol. 26, No. 4, 2014, p. 18.

18. Strupišs G. Komerclikuma komentāri: A dal̦a: Komercdarbības vispārīgie noteikumi (1.-73. pants) [Commercial Law Commentary: Part A: General Conditions of Business (Art. 1-73)]. Rīga: A. Strupiša juridiskais birojs, 2003.

19. Torremans P. The Road towards the Harmonisation of Trade Secrets Law in the European Union. Revista La Propiedad Inmaterial, No. 20, 2015, p. 27.

\section{Legislative acts}

1. Agreement on Trade-Related Aspects of Intellectual Property Rights. Signed in Marrakesh on 15.04.1994.

2. Directive (EU) 2016/943 of the European Parliament and of the Council of 8 June 2016 on the protection of undisclosed know-how and business information (trade secrets) against their unlawful acquisition, use and disclosure, 2016 OJ (L 157) $1 \mathrm{ff}$.

3. Civil Code of Lithuania. Available at: https://www.e-tar.lt/portal/lt/legalAct/TAR. 8A39C $83848 \mathrm{CB} /$ asr [last viewed October 30, 2019].

4. Civil Procedure Code of Latvia. Available at: https://vvc.gov.lv/image/catalog/dokumenti/ Civil\%20Procedure\%20Law.doc [last viewed October 30, 2019].

5. Civil Procedure Code of Lithuania. Available at: https://www.e-tar.lt/portal/lt/legalAct/ TAR.2E7C18F61454/asr [last viewed October 30, 2019].

6. Code of Civil Procedure of Estonia. English translation available at: https://www.riigiteataja. ee/en/eli/512042019002/consolide [last viewed November 2, 2019].

7. Commercial Act of Latvia. Available at: https://vvc.gov.lv/image/catalog/dokumenti/ The\%20Commercial\%20Law.doc [last viewed October 30, 2019].

8. Competition Act of Estonia. In force until 16.12.2018. English translation available at: https:// www.riigiteataja.ee/en/eli/527122017001/consolide [last viewed November 2, 2019].

9. Defend Trade Secrets Act of 2016. Available at: https://www.congress.gov/114/plaws/ publ153/PLAW-114publ153.pdf [last viewed November 1, 2019].

10. Employment Contracts Act of Estonia. English translation available at: https://www. riigiteataja.ee/en/eli/509052019005/consolide [last viewed November 2, 2019].

11. Freedom of Information Law of Latvia. Available at: https://vvc.gov.lv/image/catalog/ dokumenti/Freedom\%20of\%20Information\%20Law.docx [last viewed October 30, 2019].

12. Labour Act of Latvia. Available at: https://vvc.gov.lv/image/catalog/dokumenti/Labour\%20 Law.docx [last viewed October 30, 2019].

13. Law of Obligations Act of Estonia. English translation available at: https://www.riigiteataja. ee/en/eli/507032019001/consolide [last viewed November 2, 2019]. 
14. Law on Competition of Lithuania. Available at: https://e-seimas.lrs.lt/portal/legalAct/lt/ TAD/TAIS.77016/asr [last viewed October 30, 2019].

15. Law on Legal Protection of Trade Secrets of Lithuania. Available at: https://e-seimas.lrs.lt/ portal/legalAct/lt/TAD/86178ae24dfb11e88525a4bc7611b788?jfwid=-11gea3wdkd [last viewed October 30, 2019].

16. Restriction of Unfair Competition and Protection of Business Secrets Act of Estonia. English translation available at: https://www.riigiteataja.ee/en/eli/520122018013/consolide [last viewed November 2, 2019].

17. Trade Secret Protection Act of Latvia. Available at: https://likumi.lv/ta/id/305532komercnoslepuma-aizsardzibas-likums [last viewed October 30, 2019].

\section{Legal practice}

1. Judgment of the Supreme Court of Estonia of 21 March 2007 in case No. 3-2-1-22-07. Available at: https://www.riigikohus.ee/et/lahendid?asjaNr=3-2-1-22-07 [last viewed November 2, 2019].

2. Judgment of the Supreme Court of the Republic of Latvia of 19 November 2003 in case No. SKC-546.

3. Judgment of the Supreme Court of the Republic of Latvia of 27 February 2015 in case No. SKC-0008/2015 (C29206608). Available at: https://manas.tiesas.lv/eTiesasMvc/ nolemumi/pdf/204582.pdf [last viewed November 2, 2019].

4. Judgment of Lithuanian Supreme Court of 5 February 2016 in case No. 3K-7-6-706/2016. Available at: http://liteko.teismai.lt/viesasprendimupaieska/tekstas.aspx?id=54e950b3-eaee4ee0-865f-a7fa0e41 cf39 [last viewed November 2, 2019]. 